上江洲 由晃

(早稲田大学理工学部物理学科)

\title{
Dynamics of Dielectrics with Intrinsic Inhomogeneity
}

Yoshiaki Uesu

Department of Physics, Waseda University

\section{0}

\section{0}

\section{1. 不均一構造がもたらす巨大応答}

材料探索の従来の方法は, その材料に固有な性 質をできるだけ不純物を含まない純粋な組成をも つ単結晶を育成し, しかも分域構造の無い均一状 態にしてその応答特性を測定してきた。これを原 子のゆらぎに基づく線形応答理論で説明してきた。 しかし最近, メソスコピックなスケールの不均一 構造のゆらぎに基づく巨大応答特性が, 基礎, 応 用の両面から注目されている。代表的な例は, リ ラクサーと呼ばれているソフトな誘電応答特性を もつ一群の誘電体である. リラクサーを特徴づけ る物性は, 数万の大きな誘電率, ブロードな温度 変化, 低周波でおこる特徴的な誘電分散, 数 \%の 低い誘電損, 高い圧電効果などであり, 大容量小 型積層コンデンサー, 周波数フィルター, 超音波 プローブ, アクチュエーターなど幅広い応用分野 をもつ $[1,2]$. リラクサー特有な特性は誘電率が 最大值をとるはるか上の温度から発生する強誘電

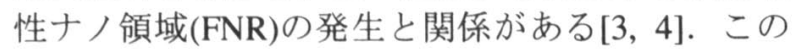
ような常誘電相と強誘電相の共存は, 1 次相転移 の転移温度の極近傍で観測される一般的な現象で あるが, リラクサーの場合にはこの 2 相共存状態 は広い温度領域で凍結し, リラクサーのプロトタ イプというべき $\mathrm{Pb}\left(\mathrm{Mg}_{1 / 3} \mathrm{Nb}_{2 / 3}\right) \mathrm{O}_{3}(\mathrm{PMN})$ の場合には, 極低温までその状態が保たれ, 平均構造は高温相 の立方晶のままで, 長距離秩序は発達しない。こ の 2 相共存の凍結は結晶中に存在するランダム場 が引き起こすと考えられているが[5], ランダム 場を作り出す原因についてはまだ定説はない。こ のような状態は一種の準安定状態であり, 小さな 刺激によって状態は大きく変化する。これが巨大 応答特性の原因と考えられる. Fig. 1 に TDGL 方 程式を用いて行った外部電場のもとでの FNR の 挙動のシミュレーション結果を示寸[6]. この図 で白いドットが FNR を表わしている. FNR にお ける分極は, PMN の場合には等価な $\{111\}$ 方向の ひとつを向く、電場が無い状態, あるいは弱い電 場のもとでは Fig. 1(a)に示寸ように FNM は小さ く, 時間的に摇らいでいる。しかし臨界電場を越 えると FNR はその分極方向を揃えて急激に成長 する(Fig. 1(b), (c), (d)).

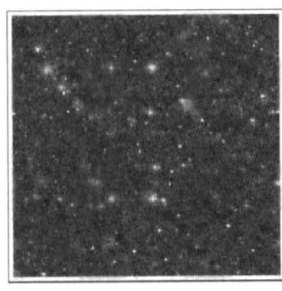

(a)

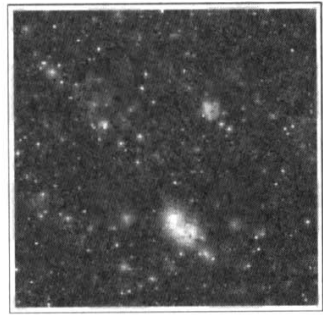

(c)

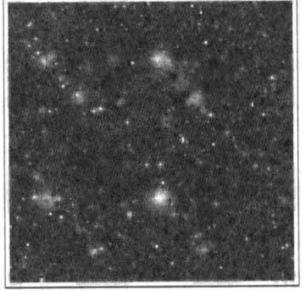

(b)

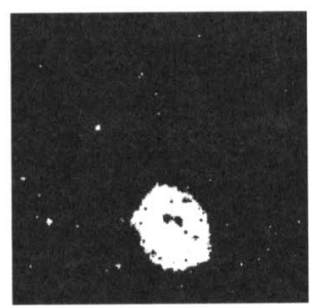

(d)
Fig. 1 Simulation of the fluctuation and growth of ferroelectric nano-regions (white dots) in nonpolar matrix (black part) under the electric field using the TDGL equation. Can we obtain the corresponding pictures directly from the neutron scattering experiments?

\section{2. 不均一構造の観察}

しかしながら，このような本質的不均一構造の 直接的, かつ明確な観察は未だなされていないの が現状である.FNR の存在は Burns が PMN につ いて屈折率の温度依存性を精密に測定し, ある温 度 Td で線形関係からずれることを見出した[7]. これから Td 以下で FNR が発生すると, 分極の ゆらぎの自乗平均 $<\delta \mathrm{P}^{2}>$ が 0 でないため, 2 次の 電気光学効果を通して屈折率が変化するとしてこ の現象を説明した. その後, 詳しい電顕観察が行 われ，FNR と思われるモットルドパターン（斑 構造）が観測された[8]. しかし電子線照射によ る温度効果や，マトリックスと FNR のコントラ ストの差が微小であることなどから, 素人が見て 納得のいく写真は得られていない。 またその大き 
さについても論文によってまちまちで数 $\mathrm{nm}$ から $\mu \mathrm{m}$ に分散している. X 線回折スペクトルの線幅 や中性子散漫散乱の解析, 中性子粉末リートベル 卜解析からもFNR に関して同様な報告はあるが いずれも間接的な証拠に留まっている.

\section{3. 中性子散乱に期待する}

このような状況の中で, BNL の Shirane らは この問題に集中的に取り組み, いくつかの興味深 い結果を得ている.ひとつは PMN について TO フォノンの分散がある波数で急激に減少すること を見出し，これを’Water Fall'現象と名付けた[9].

この波数以下ではフォノンは伝播できず, これが FNR の相関距離を与えるとした。しかしながら 相関距離の温度依存性やその分散などについては 新たな報告がない. その後 Hirota, Wakino, Shirane らは中性子散漫散乱および TO フォノンと TA フ オノンのプロファイルを詳しく調べ, TO-TA フ オノン結合が重要な役割を果たしていること, こ の解析から PNR の原子変位を具体的に求めた [10-11].

このようにリラクサー現象の本質的な解明に向 けて中性子散乱は大きな貢献をしてきたが，これ をさらに一歩進めた研究はできないであろうか.

FNR の大きさはほぼ数 $\mathrm{nm}$ から数十 $\mathrm{nm}$ といわれ ているが, Fig. 1 のような不均一構造およびその ダイナミックスあるいは外場のもとでの成長に関 して決定的な証拠を示すことはできないであろう か. さらに欲を言えば，FNR の摇らぎを直接検 出する方法はないのであろうか. これがリラクサ 一の大きな誘電率を引き起こす原因であると考え られるからである。また PMN に電場を印加する と非常に長い待ち時間ののちに長距離秩序が急激 に発達する。この待ち時間は温度と印加した電場 に依存するが，数十時間に及ぶこともある。その 振る舞いはリラクサー独特であって核成長に関す る Abrami 理論では説明できない. このことも何 らかのランダム場の存在を予想させる。電場のも とでの長距離秩序の加速は, FNR の空間的, 時 間的な相関があること, およびある臨界半径の存 在を予想している。このような相関に関する情報 も中性子から得ることはできないであろうか。

Fig. 1 に示したシミュレーションは, ランダ ム場として長距離的相互作用を示す歪みを自由工 ネルギーの中に取り組んでいる.このような仮定 は果たして正しいのであろうか. メソスコピック なスケールの不均一構造の知見は, 中性子非弾性 散乱や散漫散乱に反映しているので, 正確な情報 を得るには十分な強度が必要である。特に時間発 展の知見を得るために J-PARC に期待するところ が大きいのである。

\section{4. 本質的不均一構造はユビキタスな現象である}

このような現象はリラクサー誘電体に特有の現
象ではなく，様々な材料に現れる普遍的なもので あることも最近指摘されてきた。巨大磁気抵抗物 質[12]や電荷移動型錯体 [13]にも同様な現象が見 られ，それぞれ磁性リラクサー，有機リラクサー と名づけられている。またマルテンサイト合金に 観察される形状記憶効果, 擬弾性効果なども同じ カテゴリーに属する.さらに最近話題になってい る量子常誘電体も FNR 状態の凍結やとそのゆら ぎと密接に関連していると思われる[14].この現 象の解明は，物性物理にドメインの科学という新 しいジャンルを確立するのではないかと期待して いるのである。

\section{参考文献}

1. G. A. Smolensky, V. A. Isupov, A. I. Agranovskaya and S. N. Popov, Soviet Phys.-Solid State, 2 (1961) 2584.

2. 上江洲由晃, 固体物理, 33 (1998) 498.

3. L. E. Cross, Ferroelectrics, 76 (1987) 241.

4. Z. G. Lu and G. Calvarin, Phys. Rev. B51 (1995) 2694.

5. W. Kleemann, J. Non-Cryst. Solids, 307-310 (2002) 66.

6. Y. Uesu, K. Ishikawa and Y. Yamada, Trans. Mat. Res. Soc. Jpn, 28 (2003) 91.

7. G. Burns and F. H. Dacol, Solid State Commun., 48 (1983) 853.

8. Y. Yoshida, S. Mori, N. Yamamoto, Y. Uesu and J. Kiat, J. Korean Phys. Soc, 32 (1998) S993.

9. P. M. Gehring, S. Wakino, Z.-G. Ye and G. Shirane, Phys. Rev. Lett. 87 (2001) 277601.

10. K. Hirota, Z.-G. Ye, S. Wakino, P. M. Gehring and G. Shirane, Phys. Rev. B65 (2002) 104105.

11. S. Wakino, C. Stock, Z.-G. Ye, W. Chen, P. M. Gehring and G. Shirane, Phys. Rev. B66 (2002) 224102.

12. T. Kimura, Y. Tomioka, R. Kumai, Y. Okimoto and Y. Tokura, Phys. Rev. Lett. 83 (1999) 3940.

13. S. Horiuchi et al. Phys. Rev. Lett. 85 (2000) 5210.

14. T. Ohta, J. Phys. Soc. Jpn. 68 (1999) 2310.

\section{Abstract:}

Recent works have disclosed that intrinsic inhomogeneity of materials generates huge responses to weak outer field. A typical example is relaxor dielectrics, where the growth and fluctuation of polar nano-regions plays an important role in the soft dielectric properties. We expect the J-PARC to provide us direct evidences of the behavior of these intrinsic inhomogeneous structure of mesoscopic scale. 